\title{
Model Systems and Models of Public Relations
}

\author{
Matúš Stračiak \\ Faculty of Mass Media Communication \\ University of Ss. Cyril and Methodius \\ Trnava, Slovak Republic \\ straciak.m@gmail.com
}

\author{
Ivana Butoracová Š indleryová \\ Faculty of Social Sciences \\ University of Ss. Cyril and Methodius \\ Trnava, Slovak Republic \\ ivanasindleryova@gmail.com
}

\begin{abstract}
Common practise claimed, that there should be stated certain models in outline for relations with public. The most important need is anchorage of united and strategic form of public relations, which will be integrated into the complex marketing communication of an organization. This need is reflected only in individual models of public relations, which can vary according to needs of an organization.
\end{abstract}

Keywords-public relations; PR; models; model systems; marketing; communication

\section{BASIC DIVISION}

The most basic division of individual activities is division to internal or external public relations. It is an partial application of internal and external marketing communication. In case of public relations are obviously used implements of public relations. Absolutely necessary is a clarification of the elements of a corporate identity, which are then used in internal and external communication. For successful external communication internal environment has to be equated with a corporate identity.

Internal public relations and their executors should closely cooperate with personnel managers and creators of individual processes of internal communication. Internal public relations should be strengthening element, which will help with identifying of employees with philosophy of corporation, corporate identity and opinions of the management. Intracorporate PR and its correct performing bring mainly benefit for an organization, but also for its employees. It strengthens internal communication e.g. among individual departments. It can significantly improve processes on impulse of its employees, who are more efficiently informed about activities in the internal part of corporation. Pleasant environment and identifying with philosophy of an organization strengthens motivation of employees and strengten bounds among them. These positive effects of quality internal public relations are of course transmitted to external environment. Internal and external public relations are dependent on each other. It is extremely important to distinguish, which information are usable in which part of organization though. Wages in state institution can be in internal environment positive information for employees, but in external environment this step can be perceived as negative.

In general, external public relations overbalance internal public relations with the range of its activities. It cannot be said, if it is right and it is needed to judge individually each case. External public relations and their realization are more complicated mainly because of heterogeneousness of information recipients and need of adaptation of final wording of tidings for individual groups of recipients (e.g. journalist, expert public, government organizations) [1]. Individual models of public relations work mainly with prerequisite that priority for organization is creating of positive image.

\section{PROACTIVE AND REACTIVE MODELS}

Theoretically, the best made are two models of public relations - proactive and reactive. Both are connected with activities of public relations experts and with organization in general. Correct forming of relations with public requests emphasis on both models and we cannot say, that it is right to put in order only one of the models in complex communication of corporation. Reactive PR is mostly used in crisis communication in government sector. Model of proactive PR is needed to apply in most of the organizations and it's prerequisite to building positive relations with public. It should be in close cooperation with reactive $P R$, which provides satisfaction for demand of information.

Active PR can be marked as active medial politics too. This activity helps to provide publicity for concrete people or topics [2]. One of the biggest cons is significant control of mediatisation process and shape of final media output. It is right to emphasise, that $\mathrm{PR}$ reports should meet conditions of informational value

Proactive PR comes from a conclusion, that executor of PR activities has knowledge about important questions of this model of relations with public and it can fulfil preconditions such as:

$$
\begin{aligned}
& \text { - actuality, } \\
& \text { - new facts, } \\
& \text { - significance, } \\
& \text { - story, } \\
& \text { - conflict, } \\
& \text { - timing, }
\end{aligned}
$$

- geographical proximity. 
Prerequisite of actuality is important mainly in building of positive relationships with media. Same as every recipient of medial outputs has interest about actual information, every redactor and editor has interest about them too [3]. For creating of interest of media and public is this prerequisite extremely important.

New facts of message mean enrichment of mediated topic, or its creation. From strategic point of view it makes sense to emphasise some information and e.g. repetition in press news, but main information should be new fact.

Prerequisite of significance is mainly based on judgement, that presented topic is socially significant. This prerequisite should be fulfilled in our target group of recipients.

Attractiveness of a message is also connected with story or concrete fate. Journalists like interesting stories, same as their final receivers [4]. Agents of media like it mostly because of more attractive medial output which story gives. This is the reason why it is appropriate to give legacy to certain context and to offer those people to public, who represent organization.

Conflict is a prerequisite of making an emotional manifestation in public. Agents of media can obtain scandalous facts from employees of PR companies, which under some conditions can support need of investigative work for journalists. Open conflicts can also bring natural satisfaction after revenge.

Within proactive public relations is enormously important to work with correct timing of communication. The first meaning is about right time of submission of information to media agents. PR worker should to know certain time of working meetings in editorial offices, deadlines and different time possibilities of journalists. The second meaning of right time is based on designation of exact time distribution of proactive PR strategy within a year, month, day and hour. Such consistency is especially needed because of preventing of filling up media by information about other topics and retention timeliness topic, which organization needs to promote in media.

Geographical proximity is based mainly on the variation of contacts on media representatives in view of their geographical classification. In this way we can differentiate, where we will assert to the media individual topics, e. g. regional topics into the local media, nationwide interesting topics in the national media.

Model of proactive public relations is usable in almost all areas of business, in non - profit and in government sector. With proactive communication it is possible to provide sufficient satisfaction of demand for information from the side of media, which often prevents active searching of topics by journalists. Their activity, searching of controversial topics and limited communication from the side of organization can be liquidating for the organization in the area of media. Responsible PR employee should just go about the particular creation of a coherent strategy of model of proactive PR.

Model of reactive public relations should serve mostly to provide information requested by the media and the public. The big mistake in realization by $\mathrm{PR}$ organization is to communicate only through already freely distributed messages. The strong example of using reactive PR is possible to see in political, mostly in governmental sphere. The positive usage of this model of relationships with public is in case of crisis communication. For organization is extremely important to be prepared by crisis manuals for reactive public relations in crisis situations [5].

\section{GRUNIG'S FOUR MODELS}

James E. Grunig is the global expert in public relations. The one of his the biggest and the most valuable contribution was formulation of four models of public relations, which closely specify and in fact extend basic models of PR (proactive and reactive). The four models of relationships with public according to Grunig are: mediation to press (press agencies, publicity), informing the public, unidirectional asymmetrical model and the bidirectional symmetrical model.

Grunig's four models of relationships with public significantly contributed to facilitating the creation of strategies PR's professionals. They should also serve for spreading the theoretical knowledge of university students and participants of workshops and courses. Because of these reasons models of PR should be in future the part of all the educational materials about relationships with public.

The actual practice, progress and increasing emphasis on ethics in public relations shows, that expertly positively evaluation model is Bidirectional systematic model. This model represents real and good PR activities. It should be two - way communication, dialogue and building relationship. The important aspect is also perception of mutual reciprocity.

\section{CONCLUSION}

Media agents also have interest in cooperation with employees of public relations. It is also apparent from one part of survey of company Donath - Burson - Marsteller, in which Slovak journalists showed the biggest interest in exclusive motive for a new report, article or interview, exclusive interviews, personality profiles. Very well rated were also press conferences and briefings, surveys results and expert conferences, seminars and open days.

This knowledge confirms interest of media in discussion and deep cooperation with employees of public relations. They should be mostly intermediaries of information in modern era, not employees, who will make effort about preserving of media agents as far as possible from information from internal part of organization. Such negative practices associated with extruding of reports and propaganda was used in past mostly in politics and in modern meaning public relations seeking its application really difficult.

Each activity in public relations should be based on well prepared PR strategy. The strategy should be based on one of the models PR. The basic division of the reactive and proactive relations with public is due to the generality of the specification greatly distorted. Much more recent and in practice more useful definition was created by James E. Grunig. With this division should meet and also deal with candidates for a job in the area of relations with public before integrating in employment [6]. 


\section{REFERENCES}

[1] J. Matúšs, "Media and culture," in European Journal of Science and Theology, vol. X, Suppl. 1. Iasi, Romania: ECOZONE Publishing House, 2014, pp. 93-98.

[2] M. Solík, J. Mináriková, "Social recognition on a global scale: Opportunities and limits of media reflection," in Communication Today, vol. V, No. 2. Trnava, Slovakia: Fakulta masmediálnej komunikácie UCM, 2014, pp. 20-31.

[3] H. Pravdová, "Post-democratic and post-journalistic tendencies in postmillennium era," in European Journal of Science and Theology, vol. X, Suppl. 1. Iasi, Romania: ECOZONE Publishing House, 2014, pp. 71-80.

[4] J. Vojtek, "Some notes on the terms newspaper and magazine and their features and difference," in Communication Today, vol. II, No. 2. Trnava, Slovakia: Fakulta masmediálnej komunikácie UCM, 2011, pp. 34-43.

[5] L. Čábyová, J. Ptačin, "Benchmarking comparison of marketing communication of universities in Slovakia," in Communication Today, vol. V, No. 1. Trnava, Slovakia: Fakulta masmediálnej komunikácie UCM, 2011, pp. 54-69.

[6] D. Petranová, "Does media education at schools develop students' critical competences?," in Communication Today, vol. II, No. 1. Trnava, Slovakia: Fakulta masmediálnej komunikácie UCM, 2011, pp. 66-83. 